\title{
Weed management using crop competition in the United States: A review
}

\author{
Authors: Prashant Jha, Vipan Kumar, Rakesh K. \\ Godara, and Bhagirath S. Chauhan
}

NOTICE: this is the author's version of a work that was accepted for publication in Crop Protection. Changes resulting from the publishing process, such as peer review, editing, corrections, structural formatting, and other quality control mechanisms may not be reflected in this document. Changes may have been made to this work since it was submitted for publication. A definitive version was subsequently published in Crop Protection, (July 2016). DOI\# 10.1016/j.cropro.2016.06.021

Jha, Prashant, Vipan Kumar, Rakesh K. Godara, and Bhagirath S. Chauhan. "Weed management using crop competition in the United States: A review." Crop Protection (July 2016).

Made available through Montana State University's $\underline{\text { ScholarWorks }}$ scholarworks. montana.edu 


\title{
Weed management using crop competition in the United States: A review
}

\author{
Prashant Jha ${ }^{\text {a, * }}$, Vipan Kumar ${ }^{\text {a }}$, Rakesh K. Godara ${ }^{\text {, }}$, Bhagirath S. Chauhan ${ }^{c}$ \\ ${ }^{a}$ Montana State University-Bozeman, Southern Agricultural Research Center, Huntley, MT, USA \\ ${ }^{\mathrm{b}}$ Crop Protection Division, Monsanto Company, St. Louis, MO, USA \\ ${ }^{\mathrm{c}}$ The Centre for Plant Science, Queensland Alliance for Agriculture and Food Innovation (QAAFI), The University of Queensland, Toowoomba, Queensland, \\ Australia
}

\begin{abstract}
A B S T R A C T
Exploiting the competitive ability of crops is essential to develop cost-effective and sustainable weed management practices. Reduced row spacing, increased seeding rates, and selection of competitive cultivars can potentially manage crop-weed competition in cotton, soybean, wheat, and corn. These cultural weed management practices facilitate a more rapid development of crop canopy that adversely affect the emergence, density, growth, biomass, and subsequently the seed production of weeds during a growing season. These cultural practices can also favour the weed suppressive ability of the crop by influencing the canopy architecture traits (plant height, canopy density, leaf area index, rate of leaf area development, and leaf distribution). These crop-competition attributes can potentially reduce the risk of crop yield losses due to interference from weed cohorts that escape an early- or a late-season postemergence herbicide application. Furthermore, reduced row spacing, increased seeding rates, and weedcompetitive cultivars are effective in reducing reliance on a single site-of-action herbicides, thereby reducing the selection pressure for development of herbicide-resistant weed populations in a cropping system.
\end{abstract}

\section{Introduction}

Weeds adversely affect the crop growth and yield by competing with crops for limiting resources such as light, water, and nutrients (Harper, 1977; Swanton et al., 2015). The intensity and duration of the crop-weed competition determines the magnitude of crop yield losses (Swanton et al., 2015). Avoiding or reducing crop yield losses due to weed competition requires the utilization of diverse and effective weed management programs (Chauhan and Opeña, 2013; Swanton et al., 2015). Herbicides are the dominant tools used for weed control in global agriculture, and an annual worldwide herbicide sale is estimated to be US $\$ 27$ billion (Kraehmer, 2012). As an outcome, the over reliance on the same-site-of-action herbicide in a cropping system has resulted in an increased development of herbicide-resistant (HR) weed populations worldwide (Heap, 2016). Globally, the US ranks first, with more than 150 unique cases of HR weed evolution, followed by Europe and Australia (Heap, 2016). Commercialization of glyphosate-resistant (GR) trait in soybean [(Glycine max (L.) Merr.] (1996), cotton (Gossypium spp.) (1997), and corn (Zea mays L.) (1998) in the US, and its increasing use for weed management in these GR crops (Duke and Powles, 2009) has resulted in evolution of 15 GR weed species over the last 20 years in the North America (Johnson et al., 2009; Beckie et al., 2014; Kumar et al., 2014, 2015; Heap, 2016). In addition, HR weed populations have also been reported in wheat (Triticum aestivum L.) grown in the US (Heap, 2016). Insurgent reports on HR weed populations pose a serious threat to the sustainability of the US cropping systems. Moreover, an increasing cost of managing HR weeds in the absence of any new site-of-action herbicide discovery over the last two decades further exacerbates the problem (Duke, 2012). Current data and future projections on HR weeds strongly suggest the need for development and implementation of integrated weed management (IWM) strategies in cotton, corn, soybean, and wheat to curb the resistance problem (Norsworthy et al., 2012; Vencill et al., 2012).

Developing cost-effective and sustainable weed management strategies further necessitates the in-depth understanding of 
concepts and factors involved in crop-weed competitive interactions (Blackshaw et al., 2000; Swanton et al., 2015). The competitive ability of a crop depends on various physiological and morphological attributes that allow the crop to utilize light, water, nutrients, and other limited resources effectively in the presence of the weed pressure. A variety of cultural practices such as crop planting dates, competitive cultivars, seeding rates, row widths, cover crops, nutrient management, and irrigation strategies can manage crop-weed competition and favour the crop competitiveness against weeds (Chauhan and Opeña, 2013; Swanton et al., 2015). Furthermore, the use of reduced crop row spacing, increased seeding rates, and competitive cultivars in a cropping system can potentially minimize reliance on herbicides with the same site of action and manage HR weed seed banks (Norsworthy et al., 2012; Vencill et al., 2012). In the U.S., soybean, cotton, corn, and wheat account for more than $70 \%$ of all crop acres planted annually (Price et al., 2011). Therefore, the aim of this review article is to highlight the importance of weed management using crop competition though manipulations in crop row spacing and seeding rates and use of competitive cultivars in these crops grown in the US.

\section{Row spacing}

\subsection{Cotton}

Traditionally, cotton in the US is grown in wide rows spaced 76to $102-\mathrm{cm}$ apart. The concept of Ultra Narrow Row (UNR) spacing originated in 1990s, with cultivation of cotton in narrow rows (twin rows) with a spacing of 19-38 cm (Reddy, 2001; Wilson et al., 2007). The UNR system allows the use of higher seeding rates of cotton per unit area. The major goals of adopting the UNR cotton system are to reduce production cost, improve weed control, and increase yield as well as economic return by increasing the plant population (Parvin et al., 2000; Nichols et al., 2004). Early and rapid canopy closure under the UNR cotton system also helps conserve soil moisture and suppress weeds early in the season (Reddy, 2001; Molin et al., 2004). Several studies conducted in the US have shown a mixed response on weed control under the UNR vs. the traditional wide row $(76-102 \mathrm{~cm}$ ) cotton production system (Parvin et al., 2000; Bryson et al., 2003; Molin et al., 2004). Rogers et al. (1976) reported that only 6 weeks of weed-free period was needed to obtain high yields in cotton grown in narrow rows $(53 \mathrm{~cm})$; whereas, 10-14 weeks of weed-free period was required to obtain similar yields in wide rows $(79-106 \mathrm{~cm})$. A four-year study showed that Sida spinosa L. under the UNR cotton system had 74-82\% less total dry weight, and 71-90\% less number of capsules per plant, compared with the wide row cotton system (Molin et al., 2004). The study also reported a $67-85 \%$ decline in the total dry weight plant $^{-1}$ of Euphorbia hyssopifolia L. under the UNR vs. the wide row cotton system (Molin et al., 2004). Stephenson and Brecke (2010) found that cotton planted in 19-cm twin rows, with each set of twin rows being 76-cm apart, had greater control of Commelina benghalensis L., Senna obtusifolia L. Irwin \& Barneby, and Jacquemontia tamnifolia $\mathrm{L}$. compared with the single-row (76 cm apart) planting pattern of cotton. In addition, the end-season total weed dry biomass was reduced by $35 \%$ in the twin-row (two rows $38 \mathrm{~cm}$ apart on 102-cm beds) compared to the single-row (on 102-cm beds) cotton planting system (Reddy and Boykin, 2010). Aulakh et al. (2011) observed that sequential post-emergence applications of pyrithiobac at 2- to 4-leaf stages of conventional cotton increased the S. obtusifolia control in $38-\mathrm{cm}$ compared to $102-\mathrm{cm}$ wide rows. In contrast, Miller et al. (1983) observed no differences in total density of grass or broadleaf weed species with tillage plus trifluralin and prometryn, and tillage plus trifluralin and fluometuron treatments, in cotton grown under narrow $(51 \mathrm{~cm})$ vs. wide $(102 \mathrm{~cm})$ rows. Similarly, a minimal effect on annual grass and broadleaf weed control was observed with various pre-emergence followed by post-emergence herbicide programs in glufosinateresistant cotton planted in $38-\mathrm{cm}$ vs. $97-\mathrm{cm}$ rows (Wilson et al., 2007).

\subsection{Soybean}

Numerous studies conducted in the US have reported the potential benefits of the narrow-row spacing on weed management in soybean. The benefits are mainly attributed to the early canopy closure in the soybean planted in narrow (19- or 38-cm wide) that enhances the competitive ability of the crop against weeds, compared to wide (76 $\mathrm{cm}$ or more) rows (Steckel and Sprague, 2004; Jha et al., 2008; Jha and Norsworthy, 2009). Shibles and Weber (1966) reported that the 95\% solar light interception occurred $17 \mathrm{~d}$ earlier in the 25 -cm wide rows compared to the 102 $\mathrm{cm}$ wide rows. In addition, soybean canopy closure occurred $40 \mathrm{~d}$ earlier in soybean planted in $25-\mathrm{cm}$ vs. $76-\mathrm{cm}$ wide rows (Mickelson and Renner, 1997). Reducing soybean row spacing from 76 to $19 \mathrm{~cm}$ delayed the critical timing of weed control (CTWR) from the first-trifoliate to the third-trifoliate stage of soybean, indicating enhanced weed competitive ability of the narrow-row soybean (Knezevic et al., 2003). Reducing the soybean row spacing from 91 to $23 \mathrm{~cm}$ reduced the weed density from 16 to 2 plants $\mathrm{m}^{-2}$ and the aboveground biomass from 141 to $33 \mathrm{~g} \mathrm{~m}^{-2}$ (Yelverton and Coble, 1991). There was a greater control of Setaria faberi Herrm. and Amaranthus rudis Sauer., and an increase in soybean yield in the GR soybean planted in narrow (19- or 38-cm) vs. wide $(78-\mathrm{cm})$ rows (Young et al., 2001). Similar results on the suppressive effect of the narrow-row soybean on weed density and biomass were evident for several other weeds including, other Amaranthus species, Chenopodium album L., S. obtusifolia, Ipomoea species, Xanthium strumarium L., and Ambrosia artemisiifolia L. which are predominant in the US soybean production (Legere and Schreiber, 1989; Mickelson and Renner, 1997; Buehring et al., 2002; Steckel and Sprague, 2004; Hock et al., 2006; Harder et al., 2007). A single application of glyphosate at the V3 stage of soybean eliminated seed production from Amaranthus palmeri S. Wats plants in 19-cm soybean rows, compared with 600 seeds $\mathrm{m}^{-2}$ produced by plants grown in $97-\mathrm{cm}$ soybean rows (Jha et al., 2008). Furthermore, in majority of these studies, soybean yields were greater in narrow compared to wide rows.

A dense canopy of soybean when planted in narrow rows $(19 \mathrm{~cm})$ resulted in decreased photosynthetic active radiation (PAR) and red/far-red ratio of light available to seed on or near the soil surface under no-tillage conditions (Norsworthy, 2004). This resulted in reduced emergence of $X$. strumarium, S. obtusifolia, and A. palmeri by 33,68 , and $76 \%$, respectively, in plots in the presence compared to those in the absence of soybean (Norsworthy, 2004; Jha and Norsworthy, 2009). Thus, the early canopy formation trait of narrow-row soybean can potentially reduce weed resurgence and reduce reliance on multiple post-emergence glyphosate applications in GR soybean (Steckel and Sprague, 2004; Jha et al., 2008).

\subsection{Wheat}

There is relatively limited research conducted in the US on assessing the effect of row spacing on crop-weed competition in wheat. Nalewaja and Arnold (1970) reported that reducing the row spacing could enhance the wheat competitiveness against weeds, and improve wheat yields. There was a $12 \%$ increase in the yield of hard red winter wheat, with a decrease in the row spacing from 23 
to $7.5 \mathrm{~cm}$ in a field infested with Bromus secalinus L. (Solie et al., 1991 ). Koscelny et al. (1990) found a $20 \%$ increase in wheat yield and a $16 \%$ reduction in seed yield of $B$. secalinus, with a decrease in wheat row spacing from 23 to $8 \mathrm{~cm}$. Similarly, reducing the wheat row spacing from 30 to $10 \mathrm{~cm}$ decreased Aegilops cylindrica Host. spikelet yield from 513 to $391 \mathrm{~kg} \mathrm{ha}^{-1}$ (Kelley, 1998). Increased wheat yield and competitiveness in wheat planted in narrow rows were due to an increase in the number of tillers per unit area (Koscelny et al., 1990). A delayed canopy closure in wheat planted with wider row spacing provides opportunity for emergence of late-season weed cohorts and substantial late-season weed competition, resulting in reduced grain yield (Koscelny et al., 1990; Kelley, 1998). A narrow (11-15 cm) compared to a wide row $(23 \mathrm{~cm})$ spacing can result in a more uniform plant distribution, growth, leaf and root architecture of wheat plants, allowing them to more efficiently utilize PAR and available water and nutrients from the soil (Koscelny et al., 1990; Kelley, 1998). In the northeastern Missouri, US, light interception and leaf area index of wheat were greater when planted in $19-\mathrm{cm}$ than in $38-\mathrm{cm}$ wide rows (Sandler et al., 2015).

\subsection{Corn}

Studies conducted in the US have documented the superior weed suppression ability and yield of corn planted in narrow rows (19 or $38 \mathrm{~cm}$ ) vs. wide rows $(76 \mathrm{~cm}$ ) (Teasdale, 1995; Murphy et al., 1996; Dalley et al., 2004). Early canopy closure and increased shading of weeds resulted in an increased crop competitiveness and a reduced weed growth in narrow-vs. wide-row corn (Teasdale, 1995; Dalley et al., 2004). In a 3-year field study, Murphy et al. (1996) reported a $20 \%$ less weed biomass production in the corn planted in 50-cm compared to $75-\mathrm{cm}$ wide rows, implying a greater competitive ability of corn planted in narrow rows. Up to $60 \%$ reductions in weed biomass have been reported in corn planted in 38-cm vs. 76-cm row spacing (Shrestha et al., 2001; Tharp and Kells, 2001). Furthermore, narrow rows $(38 \mathrm{~cm})$ coupled with a higher plant population $\left(90,000\right.$ to 124,000 plants ha $\left.{ }^{-1}\right)$ resulted in an adequate weed control even at the reduced rates of herbicides in corn (Teasdale, 1995). The risk of yield loss due to weed interference from the delayed post-emergence glyphosate treatment in GR corn was reduced when the corn was planted in $38-\mathrm{cm}$ vs. $76-\mathrm{cm}$ row spacing (Dalley et al., 2004). In a study conducted in Michigan, US, corn row spacing did not affect grain yield; nevertheless, a more efficient utilization of soil moisture by corn plants grown in competition with $C$. album and $S$. faberii was evident in $36-\mathrm{cm}$ compared to 76-cm rows (Dalley et al., 2006). However, a little to no effect of row spacing on corn-velvetleaf competition was reported (Teasdale, 1998). Similarly, the row spacing had no effect on emergence or growth of weeds and the critical period of weed control (CPWC) in corn, especially at high weed densities (Johnson and Hoverstad, 2002; Dalley et al., 2006). Environmental conditions, weed density, species composition, and herbicide application timings can potentially mask the effect of row spacing on crop-weed competition (Hall et al., 1992; Dalley et al., 2006).

\section{Seeding rate}

\subsection{Cotton}

There is a limited research conducted on the effect of cotton seeding rates on crop-weed competition in the US. In a study conducted in Florida, US, control of $C$. benghalensis and S. obtusifolia increased with an increase in the cotton density from 7 to 26 plants $\mathrm{m}^{-2}$ under low levels of weed management (glyphosate plus Smetolachlor) (Stephenson and Brecke, 2010). However, the effect of cotton density on weed control was not evident at the medium [glyphosate $+S$-metolachlor followed by (fb) glyphosate] and high (glyphosate $+S$-metolachlor fb glyphosate fb MSMA + prometryn) weed management inputs (Stephenson et al., 2011). Total nodes, plant height, and total bolls per plant of cotton decreased with an increase in cotton density from 7 to 15 plants $\mathrm{m}^{-2}$ (Stephenson et al., 2011); nevertheless, the planting density had a minimal effect on cotton seed and lint yield and on fiber quality (Jones and Wells, 1997; Stephenson et al., 2011). A planting density of 13 plants $\mathrm{m}^{-2}$ in a single-row planting pattern was needed to obtain similar yield and weed control provided by a twin-row cotton planted at 7 plants $\mathrm{m}^{-2}$ (Stephenson and Brecke, 2010).

\subsection{Soybean}

Seeding rate is an important cultural practice that influences the crop-weed competition, thereby influencing weed management (Nice et al., 2001; Arce et al., 2009). Increasing the soybean-seeding rate from 124,000 to 494,000 seeds ha $^{-1}$ reduced weed interference and increased soybean yield by $48 \%$ (Oplinger and Philbrook, 1992; Harder et al., 2007; Arce et al., 2009). Nice et al. (2001) also reported a reduction in the density and biomass of $S$. obtusifolia and Solanum ptycanthum L. with an increase in soybean population from 245,000 to 481,000 or 676,000 plants ha $^{-1}$ in the narrow rows. Similar suppressive effects of increased seeding rates on crop-weed competition have been reported for several other problem weed species in soybean, including Solanum ptycanthum L., Ipomoea lacunosa, Sesbania exaltata (Raf.) Cory., Amaranthus species, and S. obtusifolia (Buehring et al., 2002; Norsworthy and Oliver, 2002a, 2002b; Rich and Renner, 2007; Place et al., 2009).

An early canopy development is an important component of cultural weed control in soybean (Buehring et al., 2002; Norsworthy and Oliver, 2002a, 2002b; Jha et al., 2008). An increase in the seeding rate from 148,200 to 469,300 seeds ha ${ }^{-1}$ increased the cumulative intercepted photosynthetic active radiation (CIPAR) during the critical period of weed control (CPWC) in soybean by $76-172 \%$ (DeWerff et al., 2014). An early canopy development with an increase in soybean population from 247,000 to 729,000 plants ha ${ }^{-1}$ improved I. lacunosa and S. exaltata control by $>30 \%$, with a glyphosate application at the V2 stage of GR soybean (Norsworthy and Oliver, 2002a). Also, a lack of complete canopy formation at the time of an early post-emergence application of glyphosate in GR soybean increased the risk of late-season weeds and consequent crop yield loss; the effect was more pronounced in soybean planted at 240,000 and 300,000 compared to 420,000 seeds ha ${ }^{-1}$ (Arce et al., 2009). A greater competitiveness of soybean planted at a high density can not only suppress lateemerging weed cohorts, but also those that survive an earlyseason post-emergence herbicide treatment (Young et al., 2001). This could potentially improve the consistency of weed management and reduce reliance on post-emergence herbicides for weed control (DeWerff et al., 2014).

\subsection{Wheat}

Several researchers in the US have documented the benefits of increasing seeding rate or plant density on increased competitive ability of wheat against weeds. For instance, a four-year study concluded that increasing the seeding rate of wheat from 50 to $300 \mathrm{~kg} \mathrm{ha}^{-1}$ reduced the Erodium cicutarium L. biomass by $53 \%$ and seed production of $E$. cicutarium by $95 \%$, and increased wheat yields by $56-498 \%$ over the four years of the study (Blackshaw et al., 2000). Avena fatua and Aegilops cylindrica are the most troublesome weeds in wheat production systems in the Great Plains and Pacific Northwest regions of the US (Heap, 2016). In Montana, US, 
increasing the spring wheat seeding rate from 175 to 280 plants $\mathrm{m}^{-2}$ increased the wheat grain yield by $12 \%$ and reduced the biomass and seed production of Avena fatua L. by 20\% (Xue and Stougaard, 2002; Stougaard and Xue, 2004). Similarly, Carlson and Hill (1985) observed an increase in competitive ability of wheat against $A$. fatua and up to $23 \%$ increase in grain yield, by increasing the wheat density from 175 to 700 plants $\mathrm{m}^{-2}$. An increase in winter wheat population density from 40 to 60 plants $\mathrm{m}^{-1}$ row also reduced $A$. cylindrica biomass by $27 \%$, weed head density by $37 \%$, and weed spikelet biomass by $47 \%$ (Yenish and Young, 2004). In a study conducted in Maine, US, increasing the spring wheat planting density from the standard practice of 400 plants $\mathrm{m}^{-2}$ to 600 plants $\mathrm{m}^{-2}$ reduced Sinapis alba L. density by $30 \%$; nevertheless, it reduced the grain protein by 5\% (Kolb et al., 2012). Optimizing the wheat-seeding rate is, therefore, also important from a grain quality standpoint (Kolb et al., 2012). With a limited information available from the US, some insights can be gained from other countries. In UK and Europe, higher wheat seeding rates enhanced the flag-leaf senescence and negatively affected the grain-filling stage and protein concentration in the wheat kernels (Gooding et al., 2002). In addition, high seeding rates can reduce wheat grain protein due to an increased intraspecific competition for available soil nitrogen (Gooding et al., 2002; Arduini et al., 2006).

\subsection{Corn}

Several studies conducted in the US demonstrated the importance of seeding rate as a cultural weed management tool in corn production. Increasing the corn seeding rates enhanced the corn leaf area and rate of canopy closure, which further improved the ability of corn plants to suppress Abutilon theophrasti Medik., one of the major problem weeds in corn production in the US (Lindquist et al., 1998). Corn planted at a high density $\left(100,000\right.$ plants ha $\left.{ }^{-1}\right)$ in 38-cm narrow rows reduced early-season weed interference, and also aided in controlling late-emerging weed cohorts (Shrestha et al., 2001). Weil (1982) observed a negative correlation between corn plant density and total weed biomass accumulation. The greater competitiveness and an early canopy development by increasing the population density of corn reduced the biomass of late-emerging weed cohorts by 41\% (Murphy et al., 1996; Williams and Boydston, 2013). Similarly, an increase in corn density reduced canopy-transmitted photosynthetic photon flux density (PPFD), and consequently the total dry matter accumulation (reduced by 89\%) of Amaranthus retroflexus L. (McLachlan et al., 1993). Furthermore, corn-induced shading caused a relatively greater allocation of dry matter to main stem than to branches of A. retroflexus, thereby influencing the weed canopy architecture (McLachlan et al., 1993). Teasdale (1998) observed a 99\% reduction in seed production of $A$. theophrasti in corn planted at 128,000 compared to 64,000 plants $\mathrm{ha}^{-1}$ seeding rate. Increasing the corn population from 59,300 to 72,900 plants ha $^{-1}$ reduced weed seed production by $50 \%$ and improved corn yields (Tharp and Kells, 2001). Williams and Boydston (2013) also observed a decline from 72 to $27 \%$ in seed production of Panicum miliaceum L. with an increase in corn seeding rate from 35,000 to 105,000 seeds ha $^{-1}$, respectively.

\section{Competitive cultivars}

\subsection{Cotton}

Only a few field studies have been conducted in the US to test the weed competitive ability of cotton cultivars. Like corn and soybean, the differential competitive ability of cotton cultivars is associated with differences in canopy development characteristics and time of maturity (Andries et al., 1974; Chandler and Merredith, 1983). Andries et al. (1974) evaluated three near-isogenic strains of cotton including okra-, super okra-, and normal-leaf type, under three different row spacings (25-, 50-, and 100-cm rows), and with various combinations of trifluralin and flumeturon for weed control and observed that okra or normal-leaf type cotton had a better lateseason weed control than the super okra-leaf strain. Chandler and Merredith (1983) found that the early-maturing cotton cultivar ('DES 21326-04') was less tolerant to early-season competition from Anoda cristata (L.) Schlecht than the late-maturing cultivar (Deltapine 16 or Stoneville 213). However, Bridges and Chandler (1987) reported no differences in the weed competitive ability between three cotton cultivars ('1209-619-7', 'TAMCOT SP37-H', and 'Stoneville 213') with different plant heights, when grown in competition with Sorghum halepense (L.) Pers. at increasing densities.

\subsection{Soybean}

Soybean cultivars grown in the US are divided into different maturity groups, from Group 0 , best adapted to region north of $46^{\circ} \mathrm{N}$, to Group IX, best adapted to southern regions like southern Florida and Texas (Zhang et al., 2007). Soybean cultivars can differ in their ability to compete with annual grass and broadleaf weeds, and can adapt to different environments by changes in plant morphology, canopy architecture, and yield variables (Burnside, 1972; McWhorter and Hartwig, 1972). Bussan et al. (1997) observed differences in weed competitive abilities between 16 soybean genotypes that were mostly associated with the differences in canopy architecture, height, and volume of the plants. For instance, a greater biomass reduction in S. obtusifolia occurred in the presence of taller soybean cultivars (maturity Group VI) (Shilling et al., 1995). Similarly, the tall soybean cultivars being more competitive, reduced seed production and seed weight of I. lacunosa by 48 and $38 \%$, respectively, compared to the short cultivars (Bennett and Shaw, 2000). Jordan (1992) found that the short-statured soybean cultivars reduced $X$. strumarium growth early in the season, while the tall cultivars had a greater suppressive effect on the weed growth late in the season. Late-maturing soybean cultivars had earlier emergence, greater seedling vigour, more rapid canopy development, and a greater competitive ability against $A$. theophrasti and Setaria italica (L.) Beauv. compared with the early-maturing cultivars (Rose et al., 1984; Nordby et al., 2007). In contrast, early-maturing soybean cultivars reduced seed production and seed weight of I. lacunosa by 76 and 49\%, respectively, compared with the late-maturing cultivars by allowing harvest before the physiological maturity of the weed (Bennett and Shaw, 2000). However, James et al. (1988) observed a lack of consistent effect of cultivar selection on S. obtusifolia interference in soybean. Similarly, Monks and Oliver (1988) did not find differences in grain yield or weed biomass between the soybean cultivars, 'Forrest' (Group V cultivar) and 'Centennial' (Group VI cultivar). Rose et al. (1984) proposed that soybean cultivars with a weed suppressive ability through allelopathy would be an added advantage to growers.

\subsection{Wheat}

Competitive cultivars apparently offer a cheap tool to consider in IWM programs. The efficiency of light interception by a particular crop cultivar contributes to its competitive ability against weeds (Holt, 1995). Crop cultivars that rapidly shade the soil surface are more competitive in suppressing the weed growth than the slow growing cultivars (Holt, 1995). Plant height, tiller number, early vigour, and leaf size strongly correlate with the suppressive 
ability of a wheat cultivar against weeds (Blackshaw et al., 1981; Mason et al., 2007). Tall spring wheat cultivars $(\geq 83 \mathrm{~cm}$ in height) were found to have a more pronounced suppressive effect on weeds than the shorter cultivars $(73-78 \mathrm{~cm}$ ) (Blackshaw et al., 1981; Wicks et al., 1986). Tall, hard red winter wheat cultivar 'Turkey' (>90 cm tall with higher number of stems/tillers $\mathrm{m}^{-2}$ ) was found to be the most competitive wheat cultivar for suppressing annual grasses including Bromus tectorum $\mathrm{L}$. in wheat production in Nebraska, US (Challaiah et al., 1986; Wicks et al., 2004). Similarly, taller, soft winter wheat cultivars had a greater grain yield and a lower seed production of $A$. cylindrica, when grown in competition (Ogg and Seefeldt, 1999). Among the eight different winter wheat cultivars tested in competition with A. cylindrica and B. secalinus, the two shorter cultivars ('TAM 107' and '2180') were the least competitive (Kelley et al., 1999). The greater weed suppressive ability of the taller cultivars was due to their greater ability to intercept PAR (Kelley et al., 1999). In contrast, 14-30\% more grain yield reductions in shorter compared to taller winter wheat cultivars occurred in the presence of the season-long interference from B. tectorum (Blackshaw, 1994). There was also a negative relationship between wheat plant height and $B$. tectorum seed yield (Challaiah et al., 1986). In addition, the ability of competitive cultivars to reduce the fecundity of a weed species should be an important consideration for managing weed seed banks and reducing reliance on herbicides.

\subsection{Corn}

Differences in weed suppression ability among genotypes is an important trait exploited both in conventional and modern corn cultivars. Plant height, canopy density, leaf area index, leaf uprightness, rate of leaf area development, and leaf distribution are the important canopy architecture traits that can determine the crop tolerance to weed interference (Lindquist et al., 1998; Lindquist and Mortensen, 1998; Sankula et al., 2004). So et al. (2009) tested 25 commercial sweet corn hybrids in the presence of $P$. miliaceum competition, and revealed that the canopy architecture was positively associated with the competitive ability of the hybrids. On the other hand, Staniforth (1961) found an earlymaturing corn hybrid to be more tolerant to a high density of Setaria glauca (L.) Beauv compared with a late-maturing hybrid. Begna et al. (2001) also observed that early-maturing, leafy reduced stature (LRS) and conventional Pioneer ('P3979') corn hybrids, had 29-44\% less total weed biomass compared with the late-maturing, big leaf (LMBL) corn hybrids, when grown under a high weed pressure. Furthermore, the differential yield loss in response to a high weed density of a modern vs. old corn hybrid was due to the differences in leaf area index, late-season PPFD, and nitrogen-use efficiency between the two hybrids (Tollenaar et al., 1994). Concerning reductions in weed biomass and fecundity, the corn hybrid 'GH2547' was 25-31\% and 70-91\% more competitive than the 'Spirit' hybrid against P. miliaceum in trials conducted in Washington and Illinois, respectively (Williams et al., 2008). Lindquist and Mortensen (1998) observed a greater reduction in the number of capsules of $A$. theophrasti by old-corn compared to moderncorn hybrids. In another study, it was reported that the 'Pioneer 3260' corn hybrid with a horizontal leaf architecture, had lower weed density, weed biomass, intercepted PAR, and weed seed production, compared to the 'Pioneer 3394' corn hybrid, with an upright leaf architecture (Sankula et al., 2004).

\section{Conclusions}

The high rate of adoption of transgenic GR soybean, cotton, and corn in the US since 1996, has meant unprecedented and often an exclusive use of this relatively simple, reliable, and cost-effective glyphosate-based weed control in these crops. Consequently, there are now evolved GR populations of A. palmeri, A. artemissifolia L., Ambrosia trifida L., Amaranthus rudis JD Sauer, and various Conyza and Lolium spp. in the US corn, soybean, and cotton production (Heap, 2016). As GR-crop technology will dominate and remain popular with growers, it is anticipated that other GR weeds will evolve in the near future, posing a greater risk to the sustainability and continued success of glyphosate and GR crops. It is to be noted that GR weeds are not yet a problem in many parts of the world, and lessons can be learnt to add weed control diversity by adopting ecological weed management approaches, thereby, maintaining the sustainability of glyphosate and GR crops for future harvests.

Ecological weed management strategies including reduced row spacing, higher seeding rates, and competitive cultivars can provide an early-season competitive advantage to the crop, facilitate an early crop canopy development, and maximize the resource utilization by the crop to reduce weed density, biomass, and seed bank additions. These strategies can potentially manage crop-weed competition in cotton, soybean, wheat, and corn. These crop competition variables can be used as an integral component of the best management practices to reduce herbicide usage and minimize herbicide selection pressure for the evolution of HR weed populations in farm fields. Reduced row spacing, increased seeding rates, and competitive cultivars can be potentially integrated into the current glyphosate resistance management programs to reduce survival and fecundity of GR weeds in GR corn, soybean, or cotton production systems; however, there is a limited research on understanding how these cultural weed control strategies relate to management of GR weeds. Future research efforts should also explore the allelopathic potential of competitive cultivars to suppress weeds in an agroecosystem.

\section{References}

Andries, J.A., Douglas, A.G., Cole, A.W., 1974. Herbicide, leaf type, and row spacing response in cotton. Weed Sci. 22, 496-499.

Arce, G.D., Pedersen, P., Hartzler, R.G., 2009. Soybean seeding rate effects on weed management. Weed Technol. 23, 17-22.

Arduini, I., Masoni, A., Ercoli, L., Mariotti, M., 2006. Grain yield, and dry matter and nitrogen accumulation and remobilization in durum wheat as affected by variety and seeding rate. Eur. J. Agron. 25, 309-318.

Aulakh, J.S., Price, A.J., Balkcom, K.S., 2011. Weed management and cotton yield under two row spacings in conventional and conservation tillage systems utilizing conventional, glufosinate-, and glyphosate-based weed management systems. Weed Technol. 25, 542-547.

Beckie, H.J., Sikkema, P.H., Soltani, N., Blackshaw, R.E., Johnson, E.N., 2014. Environmental impact of glyphosate-resistant weeds in Canada. Weed Sci. 62, 385-392.

Begna, S.H., Hamilton, R.I. Dwyer, L.M., Stewart, D.W., Cloutier, D., Assemat, L. Foroutan-pour, K., Smith, D.L., 2001. Weed biomass production response to plant spacing and corn (Zea mays) hybrids differing in canopy architecture. Weed Technol. 15, 647-653.

Bennett, A.C., Shaw, D.R., 2000. Effect of Glycine max cultivar and weed control on weed seed characteristics. Weed Sci. 48 (4), 431-435.

Blackshaw, R.E., 1994. Differential competitive ability of winter wheat cultivars against downy brome. Agron. J. 86, 649-654.

Blackshaw, R.E., Semach, G., O'Donovan, J.T., 2000. Utilization of wheat seed rate to manage redstem filaree (Erodium cicutarium) in a zero tillage cropping system. Weed Technol. 14, 389-396.

Blackshaw, R.E., Stobbe, E.H., Sturko, A.R.W., 1981. Effect of seeding dates and densities of green foxtail (Setaria viridis) on the growth and productivity of spring wheat (Triticum aestivum). Weed Sci. 29, 212-217.

Bridges, D.C., Chandler, J.M., 1987. Influence of johnsongrass density and period of competition on cotton yield. Weed Sci. 35, 63-67.

Bryson, C.T., Reddy, K.N., Molin, W.T., 2003. Purple nutsedge (Cyperus rotundus) population dynamics in narrow row transgenic cotton (Gossypium hirsutum) and soybean (Glycine max) rotation. Weed Technol. 17, 805-810.

Buehring, N.W., Nice, G.R.W., Shaw, D.R., 2002. Sicklepod (Senna obtusifolia) control in soybean (Glycine max) response to soybean row spacing and population in three weed management systems. Weed Technol. 16, 131-141.

Burnside, O.C., 1972. Tolerance of soybean cultivars to weed competition and herbicides. Weed Sci. 20, 294-297.

Bussan, A.J., Burnside, O.C., Orf, J.H., Ristau, E.A., Puettmann, K.J., 1997. Field 
evaluation of soybean (Glycine max) genotypes for weed competitiveness. Weed Sci. 45, 31-37.

Carlson, H.L., Hill, J.E., 1985. Wild oat (Avena fatua) competition with spring wheat: effects of nitrogen fertilization. Weed Sci. 34, 29-33.

Challaiah, Burnside, O.C., Wicks, G.A., Johnson, V.A., 1986. Competition between winter wheat (Triticum aestivum) cultivars and downy brome (Bromus tectorum). Weed Sci. 34, 689-693.

Chandler, J.M., Merredith Jr., W.R., 1983. Yields of three cotton (Gossypium hirsutum) cultivars as influenced by spurred anoda (Anoda cristata) competition. Weed Sci. 31, 303-307.

Chauhan, B.S., Opeña, J., 2013. Implications of plant geometry and weed control options in designing a low-seeding seed-drill for dry-seeded rice systems. Field Crops Res. 144, 225-231.

Dalley, C.D., Bernards, M.L., Kells, J.J., 2006. Effect of weed removal timing and row spacing on soil moisture in corn (Zea mays). Weed Technol. 20, 399-409.

Dalley, C.D., Kells, J.J., Renner, K.A., 2004. Effect of glyphosate application timing and row spacing on corn (Zea mays) and soybean (Glycine max) yields. Weed Technol. 18, 165-176.

DeWerff, R.P., Conley, S.P., Colquhoun, J.B., Davis, V.M., 2014. Can soybean seeding rate be used as an integrated component of herbicide resistance management? Weed Sci. 62, 625-636.

Duke, S.O., 2012. Why have no new herbicide modes of action appeared in recent years? Pest Manag. Sci. 68, 505-512.

Duke, S.O., Powles, S.B., 2009. Glyphosate-resistant crops and weeds: now and in the future. AgBioForum 12, 346-357.

Gooding, M.J., Pinyosinwat, A., Ellis, R.H., 2002. Responses of wheat grain yield and quality to seed rate. J. Agric. Sci. 138, 317-331.

Hall, M.R., Swanton, C.J., Anderson, G.W., 1992. The critical period of weed control in grain corn (Zea mays). Weed Sci. 40, 441-447.

Harder, D.B., Sprague, C.L., Renner, K.A., 2007. Effect of soybean row width and population on weeds, crop yield, and economic return. Weed Technol. 21, $744-752$.

Harper, J.L., 1977. The Population Biology of Plants. Academic Press, London, UK.

Heap, I.M., 2016. International Survey of Herbicide Resistant Weeds. www. weedscience.org (Accessed 10.03.16.).

Hock, S.M., Knezevic, S.Z., Martin, A.R., Lindquist, J.L., 2006. Soybean row spacing and weed emergence time influence weed competitiveness and competitive indices. Weed Sci. 54, 38-46.

Holt, J.S., 1995. Plant responses to light: a potential tool for weed management. Weed Sci. 43, 474-482.

James, K.L., Banks, P.A., Karnok, K.J., 1988. Interference of soybean, Glycine max, cultivars with sicklepod, Cassia obtusifolia. Weed Technol. 2, 404-409.

Jha, P., Norsworthy, J.K., 2009. Soybean canopy and tillage effects on emergence of Palmer amaranth (Amaranthus palmeri) from a natural seed bank. Weed Sci. 57, 644-651.

Jha, P., Norsworthy, J.K., Riley, M.B., Bridges Jr., W., 2008. Influence of glyphosate timing and row width on Palmer amaranth (Amaranthus palmer) and pusley (Richardia spp.) demographics in glyphosate-resistant soybean. Weed Sci. 56, 408-415.

Johnson, W.G., Davis, V.M., Kruger, G.R., Weller, S.C., 2009. Influence of glyphosateresistant cropping systems on weed species shifts and glyphosate-resistant weed populations. Eur. J. Agron. 31, 162-172.

Johnson, G.A., Hoverstad, T.R., 2002. Effect of row spacing and herbicide application timing on weed control and grain yield in corn (Zea mays). Weed Technol. 16 $548-553$.

Jones, M.A., Wells, R., 1997. Dry matter allocation and fruiting patterns of cotton grown at two divergent plant populations. Crop Sci. 37, 797-802.

Jordan, N., 1992. Differential interference between soybean (Glycine max) varieties and common cocklebur (Xanthium strumarium): a path analysis. Weed Sci. 40, 614-620.

Kelley, J.P., 1998. Impact of Cultural Practices on Jointed Goatgrass (Aegilops Cylindrica) in Wheat (Triticum aestivum). MS thesis. Oklahoma State University, Stillwater, OK, 35 pp.

Kelley, J.P., Peeper, T.F., Krenzer, E.G., 1999. Wheat cultivar characteristics affect competitive ability with grassy weeds. Proc. South. Weed Sci. Soc. 52, 62.

Kolb, L.N., Gallandt, E.R., Mallory, E.B., 2012. Impact of spring wheat planting density, row spacing, and mechanical weed control on yield, grain protein, and economic return in Maine. Weed Sci. 60, 244-253.

Knezevic, S.Z., Evans, S.P., Mainz, M., 2003. Row spacing influences the critical timing for weed removal in soybean (Glycine max). Weed Technol. 17, 666-673.

Koscelny, J.A., Peeper, T.F., Solie, J.B., Solomon, S.G., 1990. Effect of wheat (Triticum aestivum) row spacing, seeding rate, and cultivar on yield loss from cheat (Bromus secalinus). Weed Technol. 4, 487-492.

Kraehmer, H., 2012. Innovation: changing trends in herbicide discovery. Outlooks Pest Manag. 23, 115-118.

Kumar, V., Jha, P., Reichard, N., 2014. Occurrence and characterization of kochia (Kochia scoparia) populations with resistance to glyphosate in Montana. Weed Technol. 28, 122-130.

Kumar, V., Jha, P., Giacomini, D., Westra, E.P., Westra, P., 2015. Molecular basis of evolved resistance to glyphosate and acetolactate synthase-inhibitor herbicides in kochia (Kochia scoparia) accessions from Montana. Weed Sci. 63, 758-769.

Legere, A., Schreiber, M.M., 1989. Competition and canopy architecture as affected by soybean (Glycine max) row width and density of redroot pigweed (Amaranthus retroflexus). Weed Sci. 37, 84-92.

Lindquist, J.L., Mortensen, D.A., 1998. Tolerance and velvetleaf (Abutilon theophrasti) suppressive ability of two old and two modern corn (Zea mays) hybrids. Weed Sci. 46, 569-574.

Lindquist, J.L., Mortensen, D.A., Johnson, B.E., 1998. Mechanisms of corn tolerance and velvetleaf suppressive ability. Agron. J. 90, 787-792.

Mason, H.E., Navabi, A., Frick, B., O'Donovan, J., Spaner, D., 2007. Cultivar and seeding rate effects on the competitive ability of spring cereals grown under organic management in Northern Canada. Agron. J. 99, 1199-1207.

McLachlan, S.M., Tollenaar, M., Swanton, C.J., Weise, S.F., 1993. Effect of corninduced shading on dry matter accumulation, distribution and architecture of redroot pigweed (Amaranthus retroflexus). Weed Sci. 41, 568-573.

McWhorter, C.G., Hartwig, E.E., 1972. Competition of johnsongrass and cocklebur with six soybean varieties. Weed. Sci. 20, 56-59.

Mickelson, J.A., Renner, K.A., 1997. Weed control using reduced rates of postemergence herbicides in narrow and wide row soybean. J. Prod. Agric. 10, 431-437.

Miller, J.H., Carter, L.M., Carter, C., 1983. Weed management in cotton (Gossypium hirsutum) grown in two row spacings. Weed Sci. 31, 236-241.

Molin, W.T., Hugie, J.A., Hirase, K., 2004. Prickly sida (Sida spinosa L.) and spurge (Euphorbia hyssopifolia L.) response to wide row and ultra-narrow row cotton (Gossypium hirsutum L.) management systems. Weed Biol. Manag. 4, 222-229.

Monks, D.W., Oliver, L.R., 1988. Interactions between soybean (Glycine max) cultivars and selected weeds. Weed Sci. 36, 770-774.

Murphy, S.D., Yakubu, Y., Weise, S.F., Swanton, C.J., 1996. Effect of planting patterns and inter-row cultivation on competition between corn (Zea mays) and late emerging weeds. Weed Sci. 44, 856-870.

Nalewaja, J.D., Arnold, W.E., 1970. Weed control methods, losses and costs due to weeds and benefits of weed control in wheat and other small grains. In: Holstun, J.T. (Ed.), FAO International Conference on Weed Control. Weed Science Society of America, Champaign, IL, pp. 48-64.

Nice, G.R.W., Buehring, N.W., Shaw, D.R., 2001. Sicklepod (Senna obtusifolia) response to shading, soybean (Glycine max) row spacing, and population in three management systems. Weed Technol. 15, 155-162.

Nichols, S.P., Snipes, C.E., Jones, M.A., 2004. Cotton growth, lint yield, and fiber quality as affected by row spacing and cultivar. J. Cotton Sci. 8, 1-12.

Nordby, D.E., Alderks, D.L., Nafziger, E.D., 2007. Competitiveness with weeds of soybean cultivars with different maturity and canopy width characteristics. Weed Technol. 21, 1082-1088.

Norsworthy, J.K., 2004. Soybean canopy formation effects on pitted morningglory (Ipomoea lacunosa), common cocklebur (Xanthium strumarium), and sicklepod (Senna obtusifolia) emergence. Weed Sci. 52, 961-967.

Norsworthy, J.K., Oliver, L.R., 2002a. Effect of irrigation, soybean density, and glyphosate on hemp sesbania (Sesbania exaltata) and pitted morningglory (Ipomoea lacunosa) interference in soybean. Weed Technol. 16, 7-17.

Norsworthy, J.K., Oliver, L.R., 2002b. Pitted morningglory interference in drillseeded glyphosate-resistant soybean. Weed Sci. 50, 26-33.

Norsworthy, J.K., Ward, S.M., Shaw, D.R., Llewellyn, R.S., Nichols, R.L., Webster, T.M., Bradley, K.W., Frisvold, G., Powles, S.B., Burgos, N.R., Witt, W.W., Barrett, M., 2012. Reducing the risks of herbicide resistance: best management practices and recommendations. Weed Sci. 60, 31-62.

Ogg Jr., A.G., Seefeldt, S.S., 1999. Characterizing traits that enhance the competitiveness of winter wheat (Triticum aestivum) against jointed goatgrass (Aegilops cylindrica). Weed Sci. 47, 74-80.

Oplinger, E.S., Philbrook, B.D., 1992. Soybean planting date, row width, and seeding rate response in three tillage systems. J. Prod. Agric. 5, 94-99.

Parvin Jr., D.W., Cooke, F.T., Molin, W.T., 2000. Commercial ultra-narrow row cotton production, Mississippi. In: Dugger, C.P., Richter, D.A. (Eds.), Proceedings of the Beltwide Cotton Conferences. National Cotton Council of America, Memphis TN, pp. 433-436.

Place, G.T., Reberg-Horton, S.C., Dunphy, J.E., Smith, A.N., 2009. Seeding rate effects on weed control and yield for organic soybean production. Weed Technol. 23, 497-502.

Price, A.J., Balkcom, K.S., Culpepper, S.A., Kelton, J.A., Nichols, R.L., Schomberg, H., 2011. Glyphosate-resistant Palmer amaranth: a threat to conservation tillage. J. Soil Water Conserv. 66, 265-275.

Reddy, K.N., 2001. Broadleaf weed control in ultra-narrow row bromoxynil-resistant cotton (Gossypium hirsutum). Weed Technol. 15, 497-504.

Reddy, K.N., Boykin, J.C., 2010. Weed control and yield comparisons of twin- and single-row glyphosate-resistant cotton production systems. Weed Technol. 24, 95-101.

Rich, A.M., Renner, K.A., 2007. Row spacing and seeding rate effects on eastern black nightshade (solanum ptycanthum) and soybean. Weed Technol. 21, 124-130.

Rogers, N.K., Buchanan, G.A., Johnson, W.C., 1976. Influence of row spacing on weed competition with cotton. Weed Sci. 24, 410-413.

Rose, S.J., Burnside, O.C., Specht, J.E., Swisher, B.A., 1984. Competition and allelopathy between soybean and weeds. Agron. J. 76, 523-528.

Sandler, L., Nelson, K.A., Dudenhoeffer, C., 2015. Winter wheat row spacing and alternative crop effects on relay-intercrop, double-crop, and wheat yields. Intl. J. Agron. http://dx.doi.org/10.1155/2015/369243.

Sankula, S., VanGessel, M.J., Mulford, R.R., 2004. Corn leaf architecture as a tool for weed management in two production systems. Weed Sci. 52, 1026-1033.

Shibles, R.M., Weber, C.R., 1966. Interception of solar radiation and dry matter production by various soybean planting patterns. Crop Sci. 6, 55-59.

Shilling, D.G., Brecke, B.J., Hiebsch, C., MacDonald, G., 1995. Effect of soybean (Glycine max) cultivar, tillage, and rye (Secale cereale) mulch on sicklepod (Senna obtusifolia). Weed Technol. 9, 339-342. 
Shrestha, A., Rajcan, I., Chandler, K., Swanton, C.J., 2001. An integrated weed management strategy for glufosinate-resistant corn (Zea mays). Weed Technol. 15, 517-522.

So, Y.F., Williams, M.M., Pataky, J.K., 2009. Wild-proso millet differentially affects canopy architecture and yield components of 25 sweet corn hybrids. HortSci 44 408-412.

Solie, J.B., Solomon, S.G., Self, K.P., Peeper, T.F., Koscelny, J.A., 1991. Reduced row spacing for improved wheat yields in weed-free and weed-infested fields. Am. Soc. Agric. Eng. 34, 1654-1660.

Staniforth, D.W., 1961. Responses of corn hybrids to yellow foxtail competition. Weeds 9, 132-136.

Stephenson IV, D.O., Barber, L.T., Bourland, F.M., 2011. Effect of twin-row planting pattern and plant density on cotton growth, yield, and fiber quality. J. Cotton Sci. 15, 243-250

Stephenson, D.O., Brecke, B.J., 2010. Weed management in single- vs. twin-row cotton (Gossypium hirsutum). Weed Technol. 24, 275-280.

Steckel, L.E., Sprague, C.L., 2004. Late-season common waterhemp (Amaranthus rudis) interference in narrow- and wide-row soybean. Weed Technol. 18, 947-952.

Stougaard, R.N., Xue, Q.W., 2004. Spring wheat seed size and seeding rate effects on yield loss due to wild oat (Avena fatua) interference. Weed Sci. 52, 133-141.

Swanton, C.J., Nkoa, R., Blackshaw, R.E., 2015. Experimental methods for crop-weed competition studies. Weed Sci. 63 (sp1), 2-11.

Teasdale, J.R., 1995. Influence of narrow row/high population corn on weed control and light transmittance. Weed Technol. 9, 113-118.

Teasdale, J., 1998. Influence of corn (Zea mays) population and row spacing on corn and velvetleaf (Abutilon theophrasti) yield. Weed Sci. 46, 447-453.

Tharp, B.E., Kells, J.J., 2001. Effect of glufosinate-resistant corn (Zea mays) population and row spacing on light interception, corn yield, and common lambsquarters (Chenopodium album) growth. Weed Technol. 15, 413-418.

Tollenaar, M., Nissanka, S.P., Aguilera, A., Weise, S.F., Swanton, C.J., 1994. Effects of weed interference and soil nitrogen on four maize hybrids. Agron. J. 86 596-601.
Vencill, W.K., Nichols, R.L., Webster, T.M., Soteres, J.K., Mallory-Smith, C., Burgos, N.R. Johnson, W.G., McClelland, M.R. 2012. Herbicide resistance: toward an understanding of resistance development and the impact of herbicideresistant crops. Weed Sci. 60 (sp1), 2-30.

Weil, R.R., 1982. Maize-weed competition and soil erosion in unweeded maize. Trop. Agric. 59, 207-213.

Wicks, G.A., Ramsel, R.E., Nordquist, P.T., Schmidt, J.W., Challaiah, 1986. Impact of wheat cultivars on establishment and suppression of summer annual weeds. Agron. J. 78, 59-62.

Wicks, G.A., Nordquist, P.T., Baenziger, P.S., Klein, R.N., Hammons, R.H., Watkins, J.E., 2004. Winter wheat cultivar characteristics affect annual weed suppression. Weed Technol. 18, 988-998.

Williams II, M.M., Boydston, R.A., 2013. Crop seeding level: implications for weed management in sweet corn. Weed Sci. 61, 437-442.

Williams II, M.M., Boydston, R.A., Davis, A.S., 2008. Crop competitive ability contributes to herbicide performance in sweet corn. Weed Res. 48, 58-67.

Wilson, D.G., York, A.C., Jordan, D.L., 2007. Effect of row spacing on weed management in glufosinate-resistant cotton. Weed Technol. 21, 489-495.

Xue, Q., Stougaard, R.N., 2002. Spring wheat seed size and seeding rate affect wild oat demographics. Weed Sci. 50, 312-320.

Yelverton, F.H., Coble, H.D., 1991. Narrow row spacing and canopy formation reduces weed resurgence in soybeans (Glycine max). Weed Technol. 5, 169-174.

Yenish, J. Young, F, 2004. Winter wheat competition against jointed goatgrass (Aegilops cylindrica) as influenced by wheat plant height, seeding rate, and seed size. Weed Sci. 52, 996-1001.

Young, B.G., Young, J.M., Gonzini, L.C., Hart, S.E., Wax, L.M., Kapusta, G., 2001. Weed management in narrow and wide row glyphosate-resistant soybean (Glycine $\max$ ). Weed Technol. 15, 112-121.

Zhang, L.X., Kyei-Boahen, S., Zhang, J., Zhang, M.H., Freeland, T.B., Watson Jr., C.E., Liu, X.M., 2007. Modifications of optimum adaptation zones for soybean maturity groups in the USA. Crop Manag. http://dx.doi.org/10.1094/CM-20070927-01-RS 